\title{
A influência do pensamento de Romano Guardini na construção e desenvolvimento da teologia litúrgica de Joseph Ratzinger à luz das obras O Espírito da Liturgia e O Espírito da Liturgia. Uma Introdução
}

\author{
Orientador: Antonio Luiz Catelan Ferreira \\ Mestrando: Saulo da Silva Gama \\ Área de Concentração: Teologia Sistemático-Pastoral \\ Linha de Pesquisa: Fé e Cultura \\ Projeto de Pesquisa: A Teologia de Joseph Ratzinger e o Magistério de Bento \\ XVI
}

O tema da presente pesquisa é a influência do pensamento de Romano Guardini na construção e desenvolvimento da teologia litúrgica de Joseph Ratzinger. Está inserida nas atividades de pesquisa do Programa de Pós-Graduação em Teologia da PUC-Rio, área de concentração Teologia Sistemático-Pastoral, linha de pesquisa Fé e Cultura, projeto de pesquisa A Teologia de Joseph Ratzinger e o Magistério de Bento XVI. Seu principal objetivo é investigar a existência de uma coerência interna entre o pensamento do intelectual veronese com o do teólogo bávaro de tal maneira que se possa verificar se a teologia litúrgica de Joseph Ratzinger está em continuidade com o pensamento de Romano Guardini sobre a sagrada liturgia. Assim sendo, após uma primeira reflexão, que busca reaver a personalidade e o pensamento de Romano Guardini a partir a apresentação de dados biográficos, do contexto histórico/teológico e da exposição e análise de sua clássica obra litúrgica $\mathrm{O}$ Espírito da Liturgia, o estudo se desenvolve em duas abordagens sucessivas: a apresentação e análise dos princípios abordados no famoso escrito ratzingeriano $\mathrm{O}$ Espírito da Liturgia. Uma introdução e a análise comparativa entre 
os textos teológicos já citados, a fim de descobrir pontos de contato entre os pensamentos de ambos os autores, que examinam a hipótese de que parte do pensamento litúrgico de Joseph Ratzinger está construído sobre bases lançadas por Romano Guardini. O escopo desta pesquisa é contribuir para uma melhor divulgação e compreensão da teologia litúrgica de Joseph Ratzinger.

Palavras-chave: Liturgia. Movimento Litúrgico. Reforma Litúrgica. Romano Guardini. Joseph Ratzinger. 